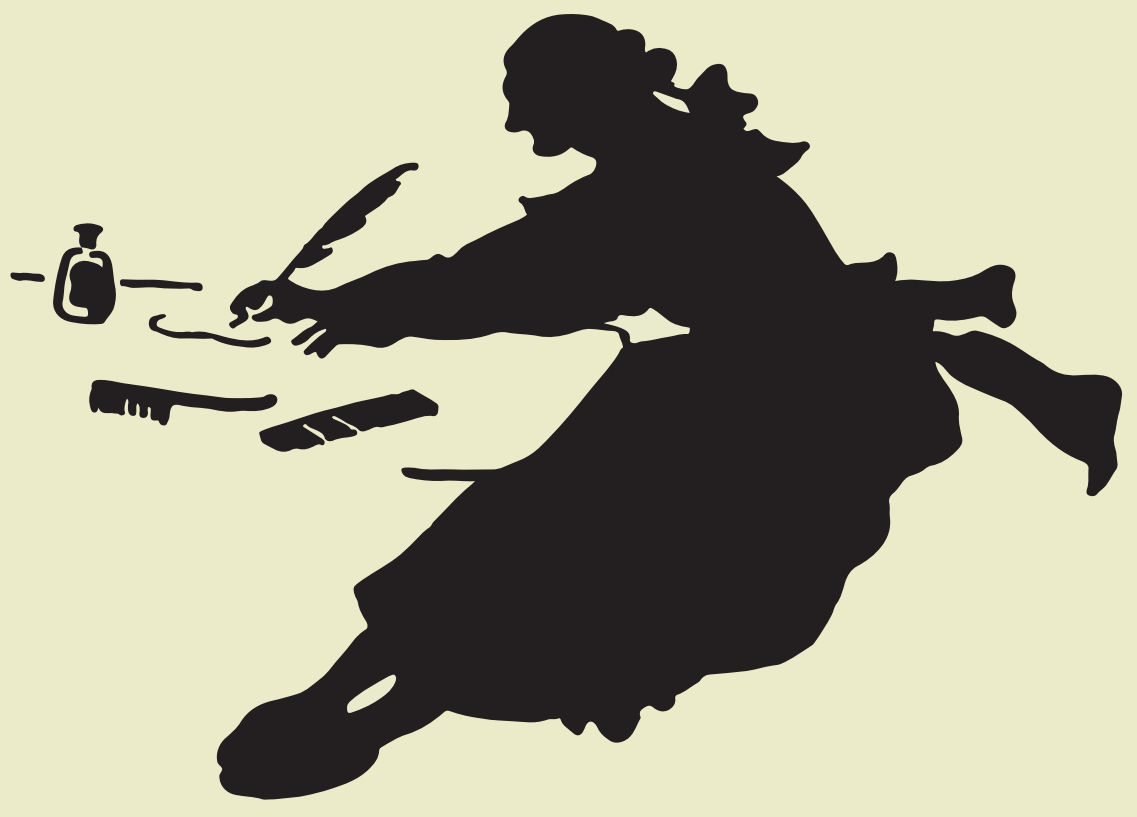

\title{
EL COMPROMÍS LITERARI EN LA MODERNITAT
} Del període d'entreguerres al postfranquisme (1920-1980)

Montserrat Corretger, Pompeu Casanovas i Vicent Salvador (eds.) 



\title{
El compromís literari en la modernitat Del període d'entreguerres al postfranquisme (1920-1980)
}

\author{
Montserrat Corretger \\ Pompeu Casanovas \\ Vicent Salvador \\ (eds.)
}
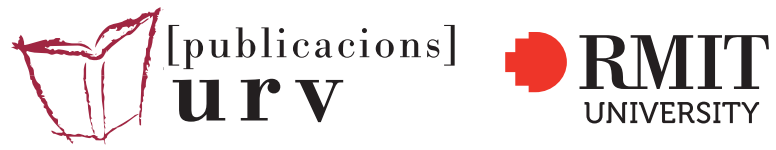

Tarragona | Melbourne
2016 


\section{Edita}

Publicacions Universitat Rovira i Virgili

Royal Melbourne Institute of Technology

1a edició: juliol de 2016

ISBN (URV): 978-84-8424-485-1

ISBN (RMIT): 978-0-9941522-5-1

DOI: $10.17345 / 9788484244455$

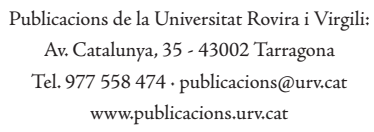

Royal Melbourne Institute of Technology 124 La Trobe Street, Melbourne VIC 3000 Phone: +61399252000 http://www.rmit.edu.au/

\section{UNIVERSITAT ROVIRA I VIRGILI}

Amb el suport del Grup de Recerca Identitats en la Literatura Catalana (GRILC) (2014 SGR 755) i de la Càtedra Josep Anton Baixeras 


\section{Índex}

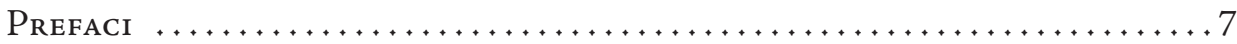

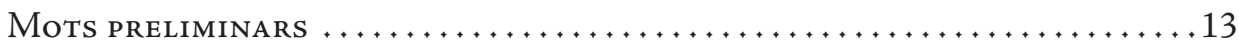

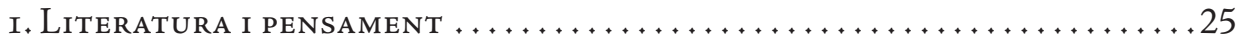

La identitat catalana: pactisme polític i compromís literari ...............22 Pompeu Casanovas

Joan Crexells i el periodisme als anys vint............................59 Xavier Serra

Entre les lletres i les arts. Lassaig filosòfic a les dècades de 1940 a 1960 . . . . . . . . . . 77 Joan Cuscó i Clarasó

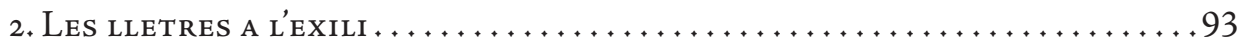

Carles Riba: un escriptor davant la literatura .........................95 Jordi Malé

Traducció i lluita política a l'exili: el grup de Xile......................107 Montserrat Bacardí

Odó Hurtado: compromís literari des de l'exili . ........................119

Montserrat Corretger

3. La literatura Sota el franquisme ............................ 145

Joan Oliver sota vigilància de la policia franquista $(1948-1977)$. . . . . . . . . . . 147

Francesc Foguet $i$ Boreu

La concepció fusteriana de la literatura com a pràctica social................159

Vicent Salvador

Josep Anton Baixeras, compromís i activisme cultural ...................177

Montserrat Palau 
Literatura periodística i compromís: Manuel de Pedrolo i l’Avui (1976-1979) ...189 Xavier Ferré Trill

Compromís i identitat urbana en la novel.la catalana dels setanta. .............209 Adolf Piquer Vidal

4. La literatura com a compromís vital . . . . . . . . . . . . . . . . . . . 223

Carles Soldevila (1892-1967): figures, veus i discurs de dones. . . . . . . . . . . . . 225

Dolors Madrenas Tinoco, Joan M. Ribera Llopis

La cara oculta de M. Aurèlia Capmany, o el fantàstic esdevingut compromís ..... 241 Alfons Gregori

«El tèrbol atzur de ser tres voltes rebel»: compromís i identitat en les obres de M. Aurèlia Capmany, Montserrat Roig i M. Mercè Marçal. . . . . . . . . . . . . . . 257 M. Àngels Francés Díez

Memòria i identitat a través dels textos autobiogràfics d'autors valencians ......269 Anna Esteve

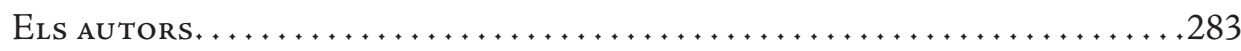


El llibre que teniu a les mans pretén analitzar les formes de relació entre l'escriptor i la societat. Aquest objectiu genèric pot semblar vague, però si ens detenim a calibrar aquesta relació en el context definit per la seixantena d'anys que van des de 1920 a 1980 podem concretar que s'aprofundeix en la funció intel-lectual de l'escriptor sota els diversos registres històrics, polítics, sociològics, culturals i artístics inclosos en aquests anys, esdevinguts centre de la modernitat. Aquest compromís intel-lectual amb la literatura serà, doncs, el fil conductor del present volum.

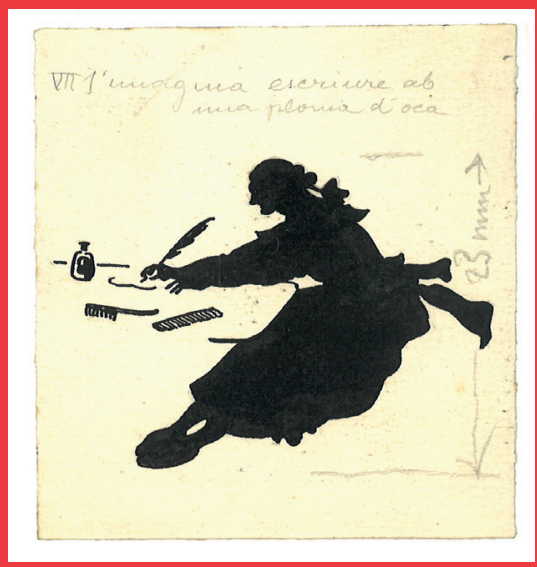

Josep Triadó, "S'imagina escriure amb una ploma d'oca", tinta xinesa sobre cartolina, 1927. Biblioteca de Catalunya. 